\title{
The Low-Temperature-Induced Viable-But-Nonculturable State Affects the Virulence of Ralstonia solanacearum Biovar 2
}

\author{
Leo S. van Overbeek, Jan H. W. Bergervoet, Frans H. H. Jacobs, and Jan D. van Elsas
}

First, second, and third authors: Plant Research International B.V., P.O. Box 16, 6700AA Wageningen, The Netherlands; and fourth author: Groningen University, Biological Center, Microbial Ecology section, P.O. Box 14, 9750AA Haren, NL.

Accepted for publication 29 December 2003.

\begin{abstract}
van Overbeek, L. S., Bergervoet, J. H. W., Jacobs, F. H. H., and van Elsas, J. D. 2004. The low-temperature-induced viable-but-nonculturable state affects the virulence of Ralstonia solanacearum biovar 2. Phytopathology 94:463-469.

The physiology and virulence of Ralstonia solanacearum biovar 2 strain 1609 , kept in water at 4 and $20^{\circ} \mathrm{C}$, were studied. At $20^{\circ} \mathrm{C}$, total cell and plate count (colony forming units; CFU) numbers were similar, between $\log 5.03$ and $\log 5.55 \mathrm{CFU}$, and $\log 5.03$ and $\log 5.51$ cells per $\mathrm{ml}$, at days 0 and 132, respectively. However, CFU in the cultures kept at $4^{\circ} \mathrm{C}$ dropped from log $6.78 \mathrm{CFU} / \mathrm{ml}$ at day 0 to below detection after 84 days. The presence of catalase in the agar resulted in higher CFU, and at day $84, \log 1.95 \mathrm{CFU} / \mathrm{ml}$ still was detectable. No colonies were observed at day 125. The presence of viable-but-nonculturable (VBNC) cells in the $4^{\circ} \mathrm{C}$ cultures was confirmed using SYTO9 viability staining. Viable cell numbers were $\log 1.77$ higher than $\mathrm{CFU}$ on plates with cata-

lase. At day 84 and after 125 days, $\log 3.70$ viable cells per ml still were present. Shifts in subpopulations differing in viability were found by flow cytometric sorting of $4^{\circ} \mathrm{C}$-treated cells stained with SYTO9 (healthy) and propidium iodide (PI; compromised). The SYTO9-stained cell fractions dropped from 99 to $39 \%$, and the PI-stained fractions increased from 0.7 to $33.3 \%$ between days 0 and 125 . At $20^{\circ} \mathrm{C}$, the SYTO9-stained fraction remained stable at $99 \%$ until day 132. SYTO9-stained cells sorted from $4^{\circ} \mathrm{C}$ cultures at day 100 were injected into tomato plants. Upon incubation for 30 days, these plants did not show wilting. However, more than $\log 4.19 \mathrm{CFU}$ and $\log 8.17$ cells were recovered from these plants. Cells from colonies isolated from the nonwilted plants did not regain their virulence as demonstrated by subsequent injection into several new sets of tomato plants. Cells from $4^{\circ} \mathrm{C}$ cultures injected at day 125 were not able to cause wilting of, or proliferate in, tomato plants. The threat posed by VBNC $R$. solanacearum cells upon incubation at $4^{\circ} \mathrm{C}$ was thus ephemeral because cells lost their capacity to cause disease after 125 days.
\end{abstract}

In recent years, outbreaks of brown rot in potato, caused by Ralstonia solanacearum biovar 2, have occurred annually in Dutch fields $(11,27)$. The pathogen is considered to be nonindigenous in temperate climate areas and, thus, has the quarantine status in the Netherlands as well as in other North European countries. For a long time, it was not completely clear how $R$. solanacearum had been introduced into potato crops in these areas, i.e., either by periodical reintroduction with seed material or via persistent infestation from the environment. Currently, it is accepted that a key source of inoculum of this organism is provided by bittersweet (Solanum dulcamara L.) plants growing in canals and ditches neighboring potato fields (35). The organism may survive harsh winter conditions relatively shielded within stems and roots of bittersweet plants or planktonically in bottom sludge in ditches (26). Therefore, the threat posed by $R$. solanacearum present in water systems in temperate climate zones will largely depend on its capacity to adapt to conditions prevailing in such freshwater environments, such as reduced nutrient availability and low temperatures.

In order to survive in the environment, $R$. solanacearum requires saprophytic capabilities in different habitats, such as soil $(8,14,27)$, canal or irrigation water $(26)$, or in association with plant debris (7). In all habitats, a remarkable persistence has been demonstrated under specific circumstances. A major factor was the fact that $R$. solanacearum turned out to be an excellent scavenger of nutrients in (water) systems virtually devoid of nutrients (carbon sources). Thus, different biovar 2 strains were able to

Corresponding author: L. S. van Overbeek; E-mail address: leo.vanoverbeek@wur.nl

Publication no. P-2004-0301-02R

(c) 2004 The American Phytopathological Society proliferate in sterile pure water $(26,33)$, in which they also could survive for long periods of time. Therefore, it can be concluded that a nutrient-limited environment is not a priori restrictive to survival of $R$. solanacearum and possibly not to its virulence. However, a temperature drop to $4^{\circ} \mathrm{C}$ led to conversion of $R$. solanacearum biovar 2 cells to a state of nonculturability (26). Nonculturability coupled with viability also has been observed in other gram-negative bacteria such as Vibrio vulnificus $(18,19)$, Aeromonas hydrophilia (12), and thermophilic Campylobacter sp. (24). There is currently much debate about the physiological status of viable-but-nonculturable (VBNC) cells $(2,3,18,34)$. In particular, it is unclear whether VBNC cells should be considered alive, dormant, dying, or even nonviable but still showing basal metabolic activity. Recently, copper-induced nonculturable $R$. solanacearum cells have become "resuscitated" in the vicinity of tomato roots and apparently retained their virulence (9), indicating that these cells were not in an irreversible trajectory to death. Resuscitation from nonculturability also has been observed in other bacterial species and different mechanisms have been invoked. Removal of oxidative stress $(6,13,16)$, relief from high-nutrient poisoning (36) or from the stress condition itself (17), and provision of growth factors such as autoinducers (quorum sensing) (22) were considered the most likely mechanisms involved.

It is not clear how the physiological status of stressed $R$. solanacearum cells affects their capacity to cause disease in susceptible host plants. Pathogenicity can be affected by mutations in genes involved in the production of exopolysaccharides, endoglucanases, or polygalacturonidases $(1,10,23)$, which are necessary for colonization and invasion of the plant and disease development, or in the central regulatory gene involved in pathogenesis in $R$. solanacearum, phcA (5).

In this study, the effect of low-temperature-induced stress on the survival and virulence of $R$. solanacearum bv. 2 cells was as- 
sessed over an extended period of time. Cells were maintained in water systems under conditions of low oxygen availability, which is considered realistic for natural conditions. Our objective was to determine the fate and potential hazard of $R$. solanacearum bv. 2 cells during the response to a low temperature challenge.

\section{MATERIALS AND METHODS}

Bacterial strain. $R$. solanacearum bv. 2 (race 3), strain 1609, was isolated by the Dutch Plant Protection service from a field cropped with potato (Solanum tuberosum L. cv. Bartina) plants carrying symptoms typical for brown rot. Strain 1609 was isolated from a diseased plant, purified, and stored in $20 \%$ glycerol at $-70^{\circ} \mathrm{C}(27)$.

Prior to each experiment, cultures from this stock were grown in $1 / 10$-strength trypticase soy broth $(0.1 \times$ TSB [Becton Dickinson, MD], $3 \mathrm{~g}$; sucrose, $1 \mathrm{~g}$; and water, 1 liter) at $27^{\circ} \mathrm{C}$ with shaking at $180 \mathrm{rpm}$. The isolate was regularly tested for its virulence on tomato. For that purpose, strain 1609 cells were injected (10 $\mu \mathrm{l}$ of a washed culture per plant) into tomato (Lycopersicon esculentum Mill., cv. Moneymaker) plants at the four- to six-leaf stage or added via soil. Treated plants were grown under a light/ dark regime of $26^{\circ} \mathrm{C}$ for $16 \mathrm{~h} / 21^{\circ} \mathrm{C}$ for $8 \mathrm{~h}$ with an air humidity of $70 \%$, which is considered optimal for disease development (7). Symptoms of bacterial wilt, i.e., wilting and leaf deterioration, and secondary effects (growth reduction and coloration of leaf veins due to production of anthocyanins), were observed within 8 to 14 days after injection.

Effect of inoculum dose on disease incidence. The virulence of strain 1609 was tested by injection of $10-\mu$ l aliquots of serial dilutions of exponentially grown cells in sterile ultrapure water into stems of young tomato plants. For that purpose, cells grown in $0.1 \times \mathrm{TSB}$ were harvested by centrifugation $(7,000 \times g, 10 \mathrm{~min}$ at $20^{\circ} \mathrm{C}$ ) and washed three times in sterile ultrapure water. Numbers of cells as colony forming units (CFU) were determined by dilution plating onto $0.1 \times$ TSB agar ([TSBA] $0.1 \times$ TSB solidified with technical agar no. 3 [1.5\%, wt/vol]) followed by incubation of plates at $27^{\circ} \mathrm{C}$ for 5 days.

Low-temperature microcosms. The effect of two temperatures, 4 and $20^{\circ} \mathrm{C}$, on the survival and virulence of strain 1609 was tested in water microcosms in three parallel experiments. Exponentially grown and washed cells of strain 1609 were transferred to triplicate $250-\mathrm{ml}$ flasks containing $100 \mathrm{ml}$ of sterile ultrapure water, establishing final population densities of between $\log 5.01$ and $\log 6.29$ cells per ml. Flasks were incubated without shaking at the appropriate temperatures, 4 and $20^{\circ} \mathrm{C}$.

At set times, 1-ml samples were aseptically removed from each flask. Aliquots $(100 \mu \mathrm{l})$ were serially diluted in sterile ultrapure water. Diluted and undiluted samples were kept at $4^{\circ} \mathrm{C}$ (for microcosms incubated at $4^{\circ} \mathrm{C}$; up to $1 \mathrm{~h}$ ) or $20^{\circ} \mathrm{C}$ (for microcosms incubated at $20^{\circ} \mathrm{C}$ ) for assessment of colony formation and potential cells to grow and cause wilting of tomato plants (described below).

Viability and culturability of bacterial cells. Viable cells of $R$. solanacearum strain 1609 were enumerated with the Live/ Dead staining kit (BacLight bacterial viability kit, Molecular Probes, Leiden, the Netherlands). Cells with intact membranes take up SYTO9, resulting in green fluorescent cells, whereas cells with compromised membranes take up propidium iodide (PI), resulting in red fluorescent cells. Green and red cells, collected on Irgalan black-stained polycarbonate membrane filters $(0.4 \mu \mathrm{m}$, Nucleopore, Scarborough, ME), were enumerated by epifluorescence microscopy at a magnification of $\times 1,000$. Total cell numbers in each sample were determined.

Cell culturability was determined by plating $100 \mu \mathrm{l}$ of multiple 10 -fold dilutions onto $0.1 \times$ TSBA (two plates per dilution) either amended or not amended with 100 units of catalase per ml (Merck, Darmstadt, Germany). For the amended medium, molten
$0.1 \times \mathrm{TSBA}$ at $47^{\circ} \mathrm{C}$ was mixed with catalase at a final concentration of 100 units/ml. Further, embedding of $10-\mu$ l subsamples in 24-well microtiter plates containing $0.1 \times$ TSBA, without catalase, was used for immunofluorescence colony staining (IFC) $(25,29,31)$. Samples (two wells per dilution) were carefully mixed with molten $0.1 \times$ TSBA in 24-well microtiter plates and the mixture was allowed to solidify at room temperature.

Petri dishes and microtiter plates were incubated at $27^{\circ} \mathrm{C}$ for 5 days. Colonies on plates were counted directly, whereas those in microtiter plates were counted under bright light (without staining) or under UV light (immunofluorescence staining) at a magnification of $\times 40(25,29,31)$.

In parallel, cells from randomly selected colonies on $0.1 \times$ TSBA obtained from infected plants (described below) were suspended in $1 \mathrm{ml}$ of sterile ultrapure water, serially diluted, and analyzed for their virulence on tomato.

Flow cytometry-assisted detection and sorting of SYTO9and PI-stained cells from 4 - and $20^{\circ} \mathrm{C}$-treated cultures. At set times, samples from the water microcosms incubated at 4 and $20^{\circ} \mathrm{C}$ were stained with SYTO9 and PI. The resulting green and red cells were enumerated with a Beckman Coulter EPICS XLMCL equipped with EXPO32-ADC software (Beckman Coulter, Miami, FL). Green fluorescence (SYTO9-stained cells) was detected by fluorescent light sensor 1 (FL1; $525 \pm 20 \mathrm{~nm}$ ), red fluorescence (PI-stained cells) by FL3 $(610 \pm 15 \mathrm{~nm})$, and $\log$ side scatter was used as the discriminator. Calibration of the flow cytometer was performed with Flow Count (Beckman Coulter). Approximately $10 \mu \mathrm{l}$ of sample was analyzed during $60 \mathrm{~s}$. Control cultures, i.e., exponentially grown live and dead cells (exponentially grown cells boiled for $1 \mathrm{~min}$ ) and mixtures of exponentially grown live and dead cells, were used for setting up color compensation. Data were analyzed using EXPO32 software (Beckman Coulter). Parameters FL1 and FL3 were dot-plotted on the $y$ and $x$ axes, respectively, relative to the incoming signals to visualize differences between green and red cells.

Cell sorting was performed on a Beckman Coulter ALTRA hypersort apparatus equipped with EXPO32-ADC software. Cells were sorted with a $70-\mu \mathrm{m}$ hypersort tip at 45.0 psi. The sorting speed was approximately 12,000 sorting events per second. Before sorting, tubing in the equipment was sterilized with a $5 \%$ hypochlorite $(\mathrm{NaOCl})$ solution and between sample analysis with $70 \%$ ethanol.

Infection of and disease development in tomato plants. The virulence of strain 1609 cells from each treatment was tested in young tomato plants at the four- to six-leaf stage using serially diluted cell suspensions. Plants (four replicates per dilution) were injected with (i) samples from water cultures incubated at 4 and $20^{\circ} \mathrm{C}$, (ii) SYTO9-stained cells sorted by flow cytometry, (iii) exponentially grown cells, (iv) cell suspensions prepared with colonies from nonwilted plants, and (v) homogenates of nonwilted plants containing $R$. solanacearum strain 1609 cells in their stem bases. Plants were grown under a light/dark regime of $26^{\circ} \mathrm{C}$ for $16 \mathrm{~h} / 21^{\circ} \mathrm{C}$ for $8 \mathrm{~h}$ and scored daily for symptoms of wilting. Plants that did not show wilting symptoms were incubated up to 30 days to detect possibly delayed disease development. These plants also were analyzed for the presence of the pathogen in their stems outside the inoculation sites. For that purpose, stem parts (approximately $2 \mathrm{~g}$ ) 2 to $3 \mathrm{~cm}$ above the sites of inoculation were surface-sterilized with $70 \%$ ethanol $(30 \mathrm{~s})$ and $1 \%$ hypochlorite solution $(1 \mathrm{~min})$ and thoroughly washed in sterile demineralized water to remove the sterilizing agents. The resulting stem parts were aseptically transferred to sterile Stomacher bags (Seward Medical, London) containing $5 \mathrm{ml}$ of sodium phosphate buffer ( $\mathrm{NaP}$ buffer: $\mathrm{Na}_{2} \mathrm{HPO}_{4} \cdot \mathrm{H}_{2} \mathrm{O}, 19.9 \mathrm{~g}$; $\mathrm{NaH}_{2} \mathrm{PO}_{4} \cdot \mathrm{H}_{2} \mathrm{O}$, $1.27 \mathrm{~g}$; and $\mathrm{H}_{2} \mathrm{O}, 1$ liter: $\mathrm{pH}$ 8.0) and pulverized with a hammer. The resulting homogenates were serially (10-fold) diluted in sterile water and analyzed for the presence of $R$. solanacearum strain 1609 cells and CFU by immunofluorescence cell (20) and 
colony staining (25), respectively. Cells and colonies were stained with a fluorescein isothiocyanate-conjugated polyclonal antiserum raised against $R$. solanacearum bv. 2 (25) prior to enumeration by epifluorescence microscopy at magnifications of $\times 1,000$ (cells) and $\times 40$ (colonies).

The $R$. solanacearum strain 1609 colonies recovered on $0.1 \times$ TSBA with catalase were discriminated from background colonies by staining with the $R$. solanacearum-specific-labeled antiserum (25). The identity of colonies that reacted with the antiserum was confirmed by BOX-polymerase chain reaction (PCR) (21) and $R$. solanacearum-specific PCR (4).

Preparation of axenic plants and root exudates. Plants were grown from surface-sterilized seeds, according to Nijhuis et al. (15), and placed in loosely capped sterile tubes containing perlite (Agra-perlite no. 2) soaked in Murashige and Skoog medium (Flow Laboratories, Irvine, UK) under a light/dark regime $\left(26^{\circ} \mathrm{C}\right.$ for $16 \mathrm{~h} / 21^{\circ} \mathrm{C}$ for $8 \mathrm{~h}$ ) up to the four- to six-leaf stage. The absence of bacterial growth was tested by plating plant extracts and growth medium on $0.1 \times$ TSBA.

Root exudates were obtained from the axenically grown plants by applying vacuum extraction to the perlite (30). The different batches of root exudate solution obtained were mixed, passed through $0.22-\mu \mathrm{m}$ filters, and distributed over sterile Eppendorf tubes. Total organic carbon content of this mix, determined in accordance with Van Ginkel et al. (28) was $0.14 \mathrm{~g} \mathrm{C} / \mathrm{L}$.

Resuscitation of cells from the VBNC state. To resuscitate cells from the VBNC state, triplicate $10-\mathrm{ml}$ samples from the $4^{\circ} \mathrm{C}$ cultures, obtained at day 125 , were used for (i) incubation at $20^{\circ} \mathrm{C}$, (ii) inoculation of axenically growing tomato plants, and (iii) incubation in tomato root exudate solution. (i) Duplicate $5-\mathrm{ml}$ aliquots from each $4^{\circ} \mathrm{C}$-treated culture were incubated at $20^{\circ} \mathrm{C}$ in 50-ml flasks without shaking. After 10 and 30 days, samples from these cultures were dilution-plated on $0.1 \times$ TSBA with and without catalase. (ii) Axenic tomato plants were challenged with $1 \mathrm{ml}$ of the $4^{\circ} \mathrm{C}$-treated cell suspensions via application to the perlite. In total, 15 plants (five plants for each replicate culture) were thus inoculated. After 30 days, plants ( 7 to $10 \mathrm{~cm}$ in size) in which the aerial parts were separated from the roots with sterile scalpels were then transferred to sterile Stomacher bags containing $5 \mathrm{ml}$ of $\mathrm{NaP}$ buffer and pulverized with a hammer. The resulting homogenates were serially diluted and replicate aliquots $(100 \mu \mathrm{l})$ of each dilution were transferred to microtiter plates for IFC analysis $(25,31)$ and to $0.1 \times$ TSBA plates with catalase. (iii) Tubes containing $900 \mu \mathrm{l}$ of root exudate solution were inoculated with $100 \mu \mathrm{l}$ from each of the three replicate cultures (five replicate tubes per culture) and incubated at $20^{\circ} \mathrm{C}$ without shaking. After 10 and 30 days, $100-\mu$ samples from each tube were plated on $0.1 \times$ TSBA with and without catalase. All plates were incubated at $27^{\circ} \mathrm{C}$ for 5 days and inspected for presence or absence of colonies.

Statistical analyses. Statistical analyses were performed on triplicate experimental systems. Comparisons were made by analysis of variance (Genstat 6th edition, Windows version, IACR Rothamsted, Harpenden, UK), and standard errors of difference were calculated. Values were considered significantly different at the 95\% (or higher) confidence level. Variables (CFU obtained by different plating methods: i.e., 0.1× TSBA with or without catalase, IFC and cell numbers obtained by SYTO9 and immunofluorescence cell staining, and total cell numbers) were log-transformed. Time of incubation at $4^{\circ} \mathrm{C}$ and serial dilutions of cell suspensions before inoculation into plants were considered experimental factors.

\section{RESULTS}

Minimal dose of $R$. solanacearum strain 1609 cells required to cause bacterial wilt in tomato. In preliminary work, plant infestation by application to roots via soil versus injection into the stem base was compared using exponentially grown cells at different densities. Inoculation via stem injection yielded consistent results; in fact, plants inoculated via soil were not consistently infected after a single application $(5 \mathrm{ml})$ of $10^{6}$ or more $R$. solanacearum 1609 cells. Hence, stem injection was the method of choice in this study.

All plants injected with suspensions containing $10^{2}$ or $10^{3} \mathrm{CFU}$ of strain 1609 per 10- $\mu$ l injection volume showed symptoms of bacterial wilt. On the other hand, suspensions with $10 \mathrm{CFU}$ per $10 \mu \mathrm{l}$ gave $75 \%$ wilt incidence in the treated plants, whereas at $1 \mathrm{CFU}$ per $10 \mu \mathrm{l}$, only one of eight plants showed wilting. This implies that a minimal dose of between 1 and $10 R$. solanacearum strain $1609 \mathrm{CFU}$ per injected volume was required to cause wilting in 12 to $75 \%$ of the tomato plants used.

Effect of low temperature on the culturability and viability of $\boldsymbol{R}$. solanacearum. Upon incubation at $20^{\circ} \mathrm{C}$, strain $1609 \mathrm{CFU}$ on $0.1 \times$ TSBA increased slightly, from $\log 5.00 \mathrm{CFU} / \mathrm{ml}$ on day 0 to $\log 5.86 \mathrm{CFU} / \mathrm{ml}$ on day 43 . CFU were then maintained at about $\log 5.6 \mathrm{CFU} / \mathrm{ml}$ for the duration of the experiment (Fig. 1A). Total cell numbers also increased, from log 5.00 cells per ml (day 0) to $\log 5.92$ cells per $\mathrm{ml}$ (day 43), and then remained roughly stable at $\log 5.6$ cells per ml until day 132 . Overall, the CFU and cell numbers were not significantly different from each other, although on one occasion (day 17) about 10-fold greater cell numbers than CFU were detected.

When incubated at $4^{\circ} \mathrm{C}$, strain $1609 \mathrm{CFU}$ (obtained by both plating on and embedding in $0.1 \times$ TSBA) declined from $\log$
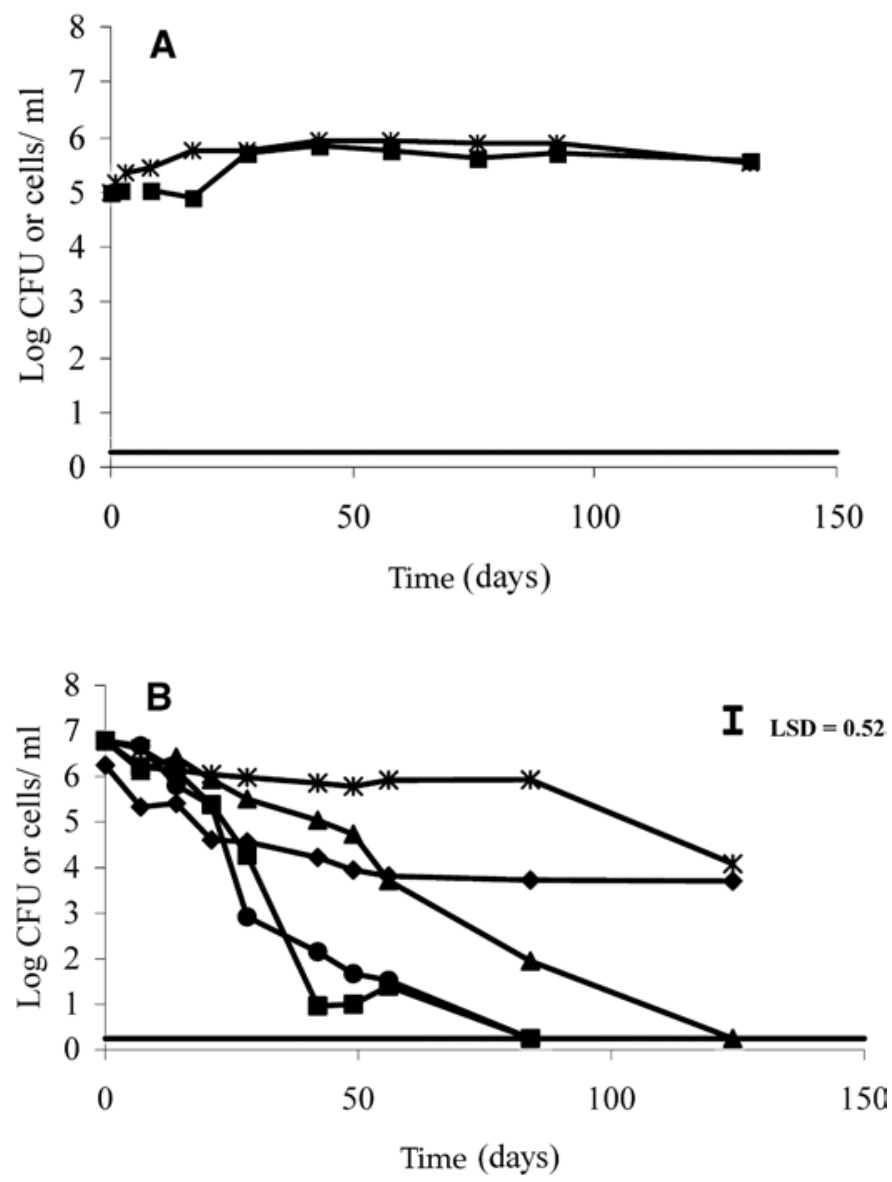

Fig. 1. Assessment of the formation of viable-but-nonculturable cells of Ralstonia solanacearum 1609 upon incubation at $\mathbf{A}, 20^{\circ} \mathrm{C}$ and $\mathbf{B}, 4^{\circ} \mathrm{C}$. $\mathbf{\square}$, CFU on $0.1 \times$ trypticase soy broth agar (TSBA); $\bullet$, colonies embedded in $0.1 \times$ TSBA (immunofluorescence colony staining approach); $\boldsymbol{\Delta}, \mathrm{CFU}$ on $0.1 \times$ TSBA with catalase; $\diamond$ SYTO9-stained (healthy) cells; $*$, total cells; and - , limit of detection $(0.25 \mathrm{CFU} / \mathrm{ml})$. LSD = least significant difference. A, No significant difference was observed between CFU on $0.1 \times$ TSBA and total cell numbers at $20^{\circ} \mathrm{C}$. 
6.78 CFU/ml to below the limit of detection $(\log 0.25 \mathrm{CFU} / \mathrm{ml}$; Fig. 1B) within 84 days. The CFU on $0.1 \times$ TSBA supplemented with catalase showed a slower decline, from $\log 6.78$ on day 0 , via $\log 1.95 \mathrm{CFU} / \mathrm{ml}$ on day 84 , to below the limit of detection on day 125. Counts on the catalase-containing plates were equal to, or about $10^{4}$ - and 100 -fold greater than those on unsupplemented $0.1 \times$ TSBA on days 0,42 , and 84 , respectively. The total cell counts, determined via staining with the Live/Dead staining kit, did not show the decline recorded for CFU. In fact, total cell numbers remained remarkably stable, with an increasing proportion of cells being able to take up PI. Both PI- and SYTO9stained cells remained at detectable levels up to 125 days. Whereas in the initial stages PI-stained cells dominated, almost equal numbers of SYTO9- (log 3.70 cells per $\mathrm{ml}$ ) and PI-stained $(\log 3.65$ cells per $\mathrm{ml})$ cells were found at day 125 . Total cell numbers were equal to (day 0 ) or about $10^{4}$-fold greater (day 84) than CFU on $0.1 \times$ TSBA with catalase. The numbers of SYTO9stained cells were initially (days 0 and 21) between three and six times lower than CFU on $0.1 \times$ TSBA with catalase, but from day 28 on, between 2- and 5,000-fold higher.

Two further replicate experiments were performed, and largely similar patterns in the dynamics of culturability and viability of strain 1609 cells were recorded (data not shown).

Heterogeneity within strain 1609 populations. The proportions of healthy (green) and compromised (red) subpopulations of strain 1609 upon incubation at 4 and $20^{\circ} \mathrm{C}$ were studied over time by staining with SYTO9 and PI followed by sorting of the green and red cells by flow cytometry. In the culture before incubation, a large green fraction (denoted I), comprising $99 \%$ of the total signal intensity, was discriminated on the FL1 axis (representing the green fluorescent signal) from a small red fraction (denoted II), comprising less than $1 \%$ of the total signal intensity, on the FL3 axis (representing the red fluorescent signal) (Table 1). A third, intermediate fraction (III), which was not closely related to either axis, and a fourth fraction (IV), related to the FL3 axis (red), comprised minute proportions of the total signal intensity. Green, red, and intermediate cell fractions remained roughly stable upon incubation of strain 1609 cells at $20^{\circ} \mathrm{C}$ up to 132 days (Table 1).

During incubation at $4^{\circ} \mathrm{C}$, both red cell fractions (II and IV) and the intermediate fraction (III) increased gradually in size after day 3. After 10 days, fraction II had increased further and fraction IV remained stable, whereas fraction III decreased. The green fraction (I) decreased to approximately 42 and $39 \%$ after 3 and 10 days (Table 1). After 100 days of incubation at $4^{\circ} \mathrm{C}$, the green fraction remained stable at around $39 \%$ of total signal intensity and was visible as a concise spot on the FL1 axis, clearly distinguishable from both the red and intermediate fractions. After 100 days, the red fraction (II) had decreased and fractions III and IV had slightly increased in size (Table 1). Inspection by epifluorescence microscopy of the sorted cell fractions from day 100 revealed that both the two red (II and IV) and the intermediate (III) fractions consisted of red cell debris with incidental intact

TABLE 1. Fractions of SYTO9- (healthy) and PI- (compromised) stained cells sorted by flow cytometry

\begin{tabular}{lccrc}
\hline \multirow{2}{*}{$\begin{array}{l}\text { Days after } \\
\text { incubation at } 4{ }^{\circ} \mathrm{C}\end{array}$} & \multicolumn{4}{c}{ Fraction $(\%)^{\mathrm{a}}$} \\
\cline { 2 - 5 } & $\mathrm{I}$ & \multicolumn{1}{c}{ II } & \multicolumn{1}{c}{ III } & \multicolumn{1}{c}{ IV } \\
\hline 0 & 99.0 & 0.7 & 0.2 & 0.1 \\
3 & 41.9 & 6.1 & 14.7 & 30.0 \\
10 & 38.7 & 18.8 & 6.3 & 29.7 \\
100 & 39.0 & 14.3 & 7.6 & 33.3 \\
\hline
\end{tabular}

${ }^{a}$ Distinguishable fractions: I, green (SYTO9-stained); II, red (PI-stained); III, intermediate; and IV, second red (PI-stained) cell fraction. Percentages of the different fractions of SYTO9- and PI-stained cells incubated at $20^{\circ} \mathrm{C}$ for 132 days and sorted by flow cytometry were: I, 98.0\%; II, 0.9\%; III, $0.1 \%$; and IV, $1.0 \%$. cells, whereas the green fraction (I) consisted solely of intact green fluorescent cells. Plating of fractions I and II onto $0.1 \times$ TSBA supplemented with catalase did not reveal any recoverable CFU. At day 132, no further shifts between the four different fractions were observed upon SYTO9- and PI-cell staining and sorting by flow cytometry (data not shown). That CFU recovery was not affected by SYTO9 staining and cell sorting was demonstrated by plating SYTO9-stained cell fractions from exponential cultures and cells incubated in microcosms at $20^{\circ} \mathrm{C}$. In these experiments, CFU were equal to the corresponding cell numbers in the sorted SYTO9-stained fractions. The SYTO9-stained fraction (I) obtained by cell sorting from suspensions incubated at $4^{\circ} \mathrm{C}$ for 100 days was analyzed for virulence by injection into tomato plants.

Recovery of $4^{\circ} \mathrm{C}$-treated cells from the VBNC state. None $(<0.05 \%)$ of the strain 1609 cells incubated for 125 days at $4^{\circ} \mathrm{C}$ was able to convert from the VBNC state to culturable forms by plating onto $0.1 \times$ TSBA with catalase. The cells incubated at $4^{\circ} \mathrm{C}$ for 125 days were then either mixed with tomato root exudates (1:1) or shifted to $20^{\circ} \mathrm{C}$ and both followed by incubation for 10 and 30 days and dilution plating on $0.1 \times$ TSBA with catalase. No CFU were observed on the resulting plates and $<0.01 \%$ of cells in root exudate solution and $<0.001 \%$ of cells at $20^{\circ} \mathrm{C}$ were culturable. Axenically grown plants were treated with the nonculturable $4^{\circ} \mathrm{C}$-treated cells (125 days) and incubated for 30 days. Extracts from treated plants were then plated onto $0.1 \times$ TSBA with catalase, as well as embedded in agar (IFC), but no CFU were recovered. These combined results indicated that 125 days of exposure to $4^{\circ} \mathrm{C}$ can lead to an irreversible state of nonculturability in $R$. solanacearum, although at the same time, substantial numbers of SYTO9-stainable cells are present in these cultures.

Effect of low temperature on the virulence of strain 1609 on tomato plants. $R$. solanacearum strain 1609 cells incubated at $20^{\circ} \mathrm{C}$ for up to 132 days, when diluted and injected into tomato plants, consistently remained virulent, evidenced by the occurrence of wilting symptoms. A minimum of 1 to 10 cells was needed to cause disease. However, when cultures incubated at $4{ }^{\circ} \mathrm{C}$ for 56 days were used, about $10^{4}$ cells were needed to cause $100 \%$ wilting of the injected plants, whereas at 10- and 100-fold dilution, only 19 and $12 \%$ of the plants showed wilting. Using these cultures incubated at $4{ }^{\circ} \mathrm{C}$ for 84 days, only $19 \%$ of the tomato plants showed wilting after injection of about $10^{4}$ cells, whereas at 10 - and 100-fold dilution, no wilted plants were observed (Table 2). The (partial) loss of virulence of the culture at day 84 coincided with the loss of culturable cells in the injected samples.

In 56 and $94 \%$ of the nonwilted plants that received about $\log 4$ and $\log 2$ cells, respectively, from the 84-day-old cultures, no strain 1609 cells were recovered. Surprisingly, in the remaining nonwilted plants, between about $\log 5$ and $\log 5.6 \mathrm{CFU}$ and $\log$ 8.5 cells per plant were found, irrespective of the number of injected cells. The dramatically increased cell numbers were estimated to be equivalent to 15 to 21 generations of growth. These findings, i.e., resuscitation to culturable forms and growth within plant tissue of cells initially in the VBNC state, were consistent in two parallel experiments. Extracts from these plants, containing between $\log 5.54$ and $\log 5.98$ cells per $10 \mu \mathrm{l}$, were successively (three times) injected into sets of new tomato plants. Growth within the plant tissue was consistently found following each transfer, but in no case was wilting observed. This indicates that the cells that had regained their ability to grow were unable to clog the vascular bundles of tomato, the prime mechanism leading to wilting. To investigate whether there was a cell concentration effect, 10 reisolates, confirmed to be $R$. solanacearum strain 1609 obtained from the nonwilted plants (day 84), were tested for their virulence on tomato. Thus, for each isolate, suspensions of $\log 3$ cells per $10 \mu \mathrm{l}$ were prepared and injected into five new tomato plants. No wilting symptoms were observed in the plants after 30 days of incubation with any of these isolates, whereas the 
control (log 3 exponentially grown $R$. solanacearum 1609 cells per $10 \mu \mathrm{l})$ wilted all five plants. Strain 1609 cells incubated for 100 days, serially (10-fold) diluted (between $\log 4.47$ and 0.47 cells per injected volume of $10 \mu \mathrm{l}$ ), and injected into tomato plants did not show wilting after 30 days, although between 13 and 26 generations of growth was observed within these plants (Table 3). Staining of cells incubated at $4^{\circ} \mathrm{C}$ for 100 days with SYTO9 and PI revealed a 10-fold greater SYTO9-stainable fraction in these cultures. Plants injected with $\log 3$ strain 1609 cells incubated for 125 days at $4^{\circ} \mathrm{C}$ all remained healthy, and strain $1609 \mathrm{CFU}$ and cells were never recovered from their stem parts (data not shown), indicating the absence of in planta resuscitation, growth, and survival.

Virulence of low-temperature-treated SYTO9-stained cells following sorting by flow cytometry. From samples taken after 100 days of incubation at $4^{\circ} \mathrm{C}$, SYTO 9 cells were sorted by flow cytometry, serially (10-fold) diluted (from $\log 4.67$ to $\log$ 0.67 cells per $10 \mu \mathrm{l}$ ), and injected into the stems of tomato plants (Table 3). None of the treated plants showed wilting 30 days after injection, whereas control plants treated with exponentially grown and SYTO9-stained $R$. solanacearum 1609 cells all wilted. SYTO9-stained strain 1609 cells sorted by flow cytometry from samples incubated for 132 days at $20^{\circ} \mathrm{C}$ were injected into tomato plants, and within 30 days, all plants showed wilting, indicating that staining with SYTO9 and sorting by flow cytometry did not affect virulence. Irrespective of the amount of cells injected, total cell and colony numbers (IFC) from the nonwilted plants were between $\log 4.19$ and $\log 5.24 \mathrm{CFU}$ and between $\log 8.17$ and $\log 8.71$ cells per plant, respectively. An increase between $10^{4}$ and $3 \times 10^{7}$ cells per plant was thus demonstrated in plants that received $\log 4.67$ and $\log 0.67$ SYTO9-stained cells, respectively, which is equivalent to 13 and 25 generations of growth. Obviously the $4^{\circ} \mathrm{C}$-treated cells stained with SYTO9 lost their virulence but not their capacity to grow in planta. In this growth, a large fraction of the resulting population again appeared as nonculturable forms.

\section{DISCUSSION}

$R$. solanacearum bv. 2 strain 1609 is affected in its physiology and survival during still incubation at $4^{\circ} \mathrm{C}$, demonstrated by the appearance of VBNC cells. The low temperature under standing (still) conditions and not exposure to pure water was the cause of the conversion and was clearly demonstrated in this study. This is consistent with earlier work in our laboratory (26). We showed that the CFU of strain 1609 remained at sustained levels after incubation at $20^{\circ} \mathrm{C}$, whereas those at $4^{\circ} \mathrm{C}$ dropped progressively to final extinction. Thus, nonculturability of cells was induced at $4^{\circ} \mathrm{C}$, and a fraction of these cells was postulated to be viable by their responses in the "direct viable count" and CTC viability assays (26).

The data presented in this study confirm that $R$. solanacearum cells respond to low temperature by a progressively increasing impairment of colony formation on agar, whereas at the same

TABLE 2. Isolation of Ralstonia solanacearum 1609 colony forming units (CFU) and cells from nonwilted tomato plants injected with low-temperature-treated cell suspensions incubated for 84 days

\begin{tabular}{|c|c|c|c|c|c|c|}
\hline \multirow{2}{*}{$\begin{array}{l}\text { Day } 84 \text { sample } \\
\text { from } 4^{\circ} \mathrm{C} \text {-treated } \\
\text { microcosms }\end{array}$} & \multicolumn{2}{|c|}{ 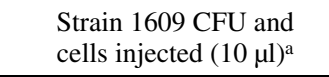 } & \multirow{2}{*}{$\begin{array}{l}\text { Number of nonwilted } \\
\text { plants possessing } \\
\text { R. solanacearum } 1609^{\mathrm{b}}\end{array}$} & \multicolumn{2}{|c|}{ Strain $1609 \mathrm{CFU}$ and cells in nonwilted plants ${ }^{\mathrm{c}}$} & \multirow{2}{*}{$\begin{array}{l}\text { Number of } \\
\text { generations }\end{array}$} \\
\hline & $\log \mathrm{CFU}$ & Log cells & & Log CFU per $g$ of plant & Log cells per $g$ of plant & \\
\hline $100 \times$ diluted & $\mathrm{BD}$ & 1.93 & $1 / 16$ & 5.55 & 8.45 & 22 \\
\hline
\end{tabular}

${ }^{a} \mathrm{BD}$, below detection. Absence of $\mathrm{CFU}$ was determined by plating $10-\mu 1$ samples on $0.1 \times$ trypticase soy broth agar with catalase $(<\log 1.7 \mathrm{CFU} / \mathrm{ml})$.

${ }^{\mathrm{b}}$ Number of plants not showing wilt and containing $>\log 0.25$ CFU per g of fresh stem or $>\log 4$ cells per $g$ of fresh stem. Three out of 16 plants treated with undiluted samples showed wilting after 30 days.

${ }^{\mathrm{c}} \mathrm{CFU}$ and cell numbers were obtained from infected plants by immunofluorescence colony staining and immunofluorescence cell enumeration, respectively. Numbers of CFU and cells were determined in stem parts. No significant difference between CFU and cell numbers was observed between plants that received different levels of inoculum. Cell numbers were significantly higher than corresponding CFU extracted from nonwilted plants.

${ }^{\mathrm{d}}$ The number of generations was calculated from the numbers of cells injected into plants and the numbers of immunofluorescence-stainable cells isolated from these plants.

TABLE 3. Development of Ralstonia solanacearum strain 1609 in tomato plants after injection of SYTO9- and PI-stained cells and SYTO9-stained cells sorted by flow cytometry ${ }^{\mathrm{a}}$

\begin{tabular}{|c|c|c|c|c|c|c|}
\hline $\begin{array}{l}\text { SYTO9-stained cells } \\
\text { sorted by flow cytometry }\end{array}$ & \multicolumn{3}{|c|}{ Strain $1609 \mathrm{CFU}$ and cells injected $(10 \mu \mathrm{l})^{\mathrm{b}}$} & \multicolumn{2}{|c|}{$\begin{array}{l}\text { Strain } 1609 \text { CFU and cell numbers } \\
\text { in nonwilted plants }{ }^{c}\end{array}$} & $\begin{array}{l}\text { Number of } \\
\text { generations }{ }^{\mathrm{d}}\end{array}$ \\
\hline Undiluted & $\mathrm{BD}$ & 4.43 & 3.43 & 5.01 & 8.40 & 13 \\
\hline $100 \times$ diluted & $\mathrm{BD}$ & 2.43 & 1.43 & 6.28 & 8.36 & 20 \\
\hline $1,000 \times$ diluted & $\mathrm{BD}$ & 1.43 & 0.43 & 5.92 & 8.53 & 24 \\
\hline $10,000 \times$ diluted & $\mathrm{BD}$ & 0.43 & $<0.1$ & 5.65 & 8.23 & 26 \\
\hline $1,000 \times$ diluted & $\mathrm{BD}$ & 1.67 & $\mathrm{BD}$ & 4.81 & 8.36 & 23 \\
\hline $10,000 \times$ diluted & BD & 0.67 & $\mathrm{BD}$ & 5.14 & 8.17 & 25 \\
\hline
\end{tabular}

${ }^{a}$ Cells had been incubated at $4^{\circ} \mathrm{C}$ for 100 days prior to staining and sorting by flow cytometry.

${ }^{\mathrm{b}} \mathrm{BD}$, below detection. Absence of CFU was determined by plating $10-\mu \mathrm{l}$ samples on $0.1 \times$ trypticase soy broth agar with catalase (<log $\left.1.7 \mathrm{CFU} / \mathrm{ml}\right)$. Limit of detection: $\log 2$ cells per ml. PI-stained cells were counted in the undiluted samples and further estimated in diluted samples.

${ }^{\mathrm{c}} \mathrm{CFU}$ and cell numbers were obtained from infected plants by immunofluorescent colony staining and immunofluorescence cell enumeration, respectively. Numbers of CFU and cells were determined in stem parts. No significant difference between CFU and cell numbers was observed between plants that received different levels of inoculum. Cell numbers were significantly higher than corresponding CFU extracted from nonwilted plants.

${ }^{d}$ The number of generations was calculated from the numbers of cells injected into plants and the numbers of immunofluorescence-stainable cells isolated from these plants. 
time, cell membrane integrity is maintained to a considerable extent, indicated by the efficient uptake of SYTO9 and exclusion of PI by a large fraction of the cells. Interestingly, the impairment of colony formation could be partially restored by the addition of catalase to the plating medium. The effect of catalase in respect of the restoration of colony forming ability also has been observed in other gram-negative species, i.e., Escherichia coli and A. hydrophilia exposed to $4^{\circ} \mathrm{C}(13,32)$. Thus, this effect is not restricted to $R$. solanacearum. The physiological status of cells in the state of nonculturability has been reviewed $(2,3,18,34)$. In line with the hypotheses laid down in these reviews, we hypothesized that, as a result of the low temperature treatment, $R$. solanacearum cells were affected in their physiological (metabolic) capacities by some kind of damage to cellular processes important for recovery from the $4^{\circ} \mathrm{C}$ stress. The fact that catalase was able to counteract this effect lends support to the hypothesis that oxidative stress was involved. Oxidative damage of bacterial proteins was proposed as the mechanism for deterioration of VBNC E. coli cells (6). Next to considerations about the mechanisms underlying the effects seen, key questions for practical purposes are: what is the consequence of exposure to low temperature for the virulence of $R$. solanacearum bv. 2 to susceptible plants and how can these data be extrapolated to natural environmental conditions?

Overall, our data showed that the virulence of the low-temperature-exposed $R$. solanacearum 1609 cells declined progressively. Cells were able to cause wilting of tomato plants until day 84 and this phase was characterized by the potential of a diminishing fraction of the cells to form colonies on $0.1 \times$ TSBA supplemented with catalase. In nature, bacterial wilt might thus be expected to occur only in susceptible plants upon infection by low-temperature-exposed $R$. solanacearum cells if these are still culturable on catalase-containing plates. Between 84 and 100 days after the onset of the low temperature stress, $R$. solanacearum cultures lost their virulence, evidenced by the absence of wilting of tomato plants. However, they still contained cellular forms capable of proliferating in tomato plants, which remained healthy. After 125 days of incubation at $4^{\circ} \mathrm{C}$, the cells were no longer able to proliferate in tomato plants, indicating that strain 1609 cells become progressively more injured. The effects on cellular physiology and metabolism may have ultimately inflicted damage to key cellular processes involved in the response to (low) substrate (i.e., growth). The detection of $R$. solanacearum 1609 cell numbers vastly exceeding CFU demonstrated that nonculturable cells also occurred in plants, which is in line with observations made by Grey and Steck (9). However, in their study, cells converted to virulence upon application to soil in the vicinity of plants roots. The discrepancy between the data in their study and in ours may be explained by differences in the experimental set-up, such as the use of sterile plants and soil, different strains, and the application of cupric sulfate instead of low temperature as inducer of the VBNC state in $R$. solanacearum cells.

The occurrence of a catalase-recoverable stage in $R$. solanacearum cells shown in this study to result from short exposure to low temperature may be equivalent to the effects of so-called mild stress. Long-term exposure to low temperature, however, may equate to a more severe stress. Under conditions of severe stress, cells might be predicted to become nonvirulent and nonresuscitable. From our current study, it is not clear which mechanism induced the loss of virulence in the cold-stressed $R$. solanacearum cells, but it is tempting to speculate that some genetic mechanism, e.g., a genetic switch or rearrangement of any kind possibly taking place in a subset (fraction) of the total $R$. solanacearum population, was involved. However, a second possibility that nonaggressive forms are positively selected during proliferation inside plants cannot be excluded. Metabolic arrest of originally aggressive cells, in some way connected to a genetic inactivation of functions involved in the wilting process, is an obvious possibility.
Considering that low numbers (between 1 and 10) of freshly grown $R$. solanacearum strain 1609 cells were sufficient to cause bacterial wilt in tomato, it may seem puzzling that vast numbers of apparently nonvirulent $R$. solanacearum cells were present in the nonwilted plants. The lack of reversion from the nonvirulent to the virulent state of $4^{\circ} \mathrm{C}$-treated cells after successive transfers to novel tomato plants indicated that the acquired nonvirulence was genetically or physiologically stable. The occurrence of nonwilted plants was probably not associated with plant responses to the challenge with vast amounts of cell debris, as supported by the data obtained with the sorted VBNC cells. Most likely, $R$. solanacearum cells become progressively "injured" during incubation at $4^{\circ} \mathrm{C}$ and concomitantly lose virulence. In the course of the low temperature challenge, a particular heterogeneity apparently develops in the culture, and strikingly, a substantial subfraction that is stainable with SYTO9 and thus, presumably possessed a functional membrane, persists. At the same time, or when exposed to plant tissue, a change of genetic or physiological nature may take place in this or another subfraction of the cultures giving rise to cells found to be nonvirulent yet growth-proficient following plant passage. It is a challenge for future studies to establish the nature of this hypothetical change to nonvirulence. The impairment in the cellular system most probably interferes with exopolysaccharide production of the cold-treated $R$. solanacearum cells residing in plants, by which clogging of vascular bundles, and thus wilting, do not occur. Moreover, in practical terms, our data, even though they suggest that the threat posed by $4^{\circ} \mathrm{C}$-exposed cells is probably ephemeral, are as yet not sufficiently exhaustive to suggest that these cells are absolutely "safe" with respect to the hypothetical lack of reversibility to pathogenicity. In nature, $R$. solanacearum cells may occupy different habitats such as host plant ( $S$. dulcamara) tissue, sediment, and bulk water $(11,26,27)$, all differently protective against stress, which likely has its effect on physiological adaptation and virulence. The effect of low temperature on survival and virulence of $R$. solanacearum in climatically temperate regions like Northwest Europe may thus be more complicated than expected from studies in the laboratory and, ultimately, conclusive data on persistence and safety must be obtained from studies in open environments.

\section{ACKNOWLEDGMENTS}

This work was supported by the EU-FAIR (FATE) and EU-Framework V-Quality of Life-(POTATOCONTROL) projects. We thank E. González (University of Wisconsin, Madison) and J. van Vuurde (Plant Research International, B.V., Wageningen, The Netherlands) for excellent technical assistance and helpful discussions.

\section{LITERATURE CITED}

1. Araud-Razou, I., Vasse, J., Montrozier, H., Etchebar, C., and Trigalet, A. 1998. Detection and visualization of the major acidic exopolysaccharide of Ralstonia solanacearum and its role in tomato root infection and vascular colonization. Eur. J. Plant Pathol. 104:795-809.

2. Barer, M. R., and Harwood, C. R. 1999. Bacterial viability and culturability. Adv. Microbiol. Physiol. 41:94-137.

3. Bogosian, G., and Bourneuf, E. V. 2001. A matter of bacterial life and death. EMBO Rep. 21:770-774.

4. Boudazin, G., Le Roux, A. C., Josi, K., Labarre, P., and Jouan, B. 1999. Design of division specific primers of Ralstonia solanacearum and application to the identification of European isolates. Eur. J. Plant Pathol. 105:373-380.

5. Clough, S. J., Lee, K., Schell, M. A., and Denny, T. P. 1997. A two component system in Ralstonia (Pseudomonas) solanacearum modulates production of a PhcA-regulated virulence factors in response to 3-hydroxypalmitic acid methyl ester. J. Bacteriol. 179:3639-3648.

6. Desnues, B., Cuny, C., Grégori, G., Dukan, S., Aguilaniu, H., and Nyström, T. 2003. Differential oxidative damage and expression of stress defence in culturable and non-culturable Escherichia coli cells. EMBO Rep. 4:400-404.

7. Graham, J., and Lloyd, A. B. 1975. An improved indicator plant method for the detection of Pseudomonas solanacearum race 3 in soil. Plant Dis. Rep. 62:35-37. 
8. Granada, G. A., and Sequiera, L. 1983. Survival of Pseudomonas solanacearum in soil, rhizosphere, and plant roots. Can. J. Microbiol. 29: 433-440.

9. Grey, B. E., and Steck, T. R. 2001. The viable but nonculturable state of Ralstonia solanacearum may be involved in long-term survival and plant infection. Appl. Environ. Microbiol. 67:3866-3872.

10. Huang, Q., and Allen, C. 2000. Polygalacturonases are required for rapid colonization and full virulence of Ralstonia solanacearum on tomato plants. Physiol. Mol. Plant Pathol. 57:77-83.

11. Janse, J. D., Araluppen, F. A. X., Schans, J., Wenneker, M., and Westerhuis, W. 1998. Experiences with bacterial brown rot Ralstonia solanacearum biovar 2, race 3 in the Netherlands. Pages 146-152 in: Bacterial Wilt Disease. Molecular and Ecological Aspects. P. Prior, C. Allen, and J. Elphinstone, eds. Springer-Verlag, Heidelberg, Germany.

12. Mary, P., Chihib, N. E., Charafeddine, O., Defives, C., and Hornez, J. P. 2002. Starvation survival and viable but nonculturable states in Aeromonas hydrophila. Microbiol. Ecol. 43:250-258.

13. Mizunoe, Y., Wai, S. N., Takade, A., and Yoshida, S. 1999. Restoration of culturability of starvation-stressed and low-temperature-stressed Escherichia coli $\mathrm{O} 157$ cells by using $\mathrm{H}_{2} \mathrm{O}_{2}$-degrading compounds. Arch. Microbiol. 172:63-67.

14. Moffett, M. L., Giles, J. E., and Wood, B. A. 1983. Survival of Pseudomonas solanacearum biovars 2 and 3 in soil: Effect of moisture and soil type. Soil Biol. Biochem. 15:587-591.

15. Nijhuis, E. H., Maat, M. J., Zeegers, I. W., Waalwijk, C., and van Veen, J. A. 1993. Selection of bacteria suitable for introduction into the rhizosphere of grass. Soil Biol. Biochem. 25:885-895.

16. Nyström, T. 1998. To be or not to be: The ultimate decision of the growth-arrested bacterial cell. FEMS Microbiol. Rev. 21:283-290.

17. Ohtomo, R., and Saito, M. 2001. Increase in the culturable cell number of Escherichia coli during recovery from saline stress: Possible implication for resuscitation from the VBNC state. Microbiol. Ecol. 42:208-214.

18. Oliver, J. D. 2000. The viable but nonculturable state and cellular resuscitation. Pages 723-730 in: Microbial Biosystems: New Frontiers, Proc. 8th Int. Symp. Microbial Ecol. C. R. Bell, M. Brylinski, and P. Johnson-Green, eds. Atlantic Canada Society for Microbial Ecology, Halifax, Canada.

19. Oliver, J. D., Hite, F. H., McDougald, D., Andon, N. L., and Simpson, L. M. 1995. Entry into, and resuscitation from, the viable but nonculturable state by Vibrio vulnificus in an estuarine environment. Appl. Environ. Microbiol. 61:2624-2630.

20. Postma, J., van Elsas, J. D., Govaert, J. M., and van Veen, J. A. 1988. The dynamics of Rhizobium leguminosarum biovar Trifolii introduced into soil as determined by immunofluorescence and selective plating techniques. FEMS Microbiol. Ecol. 53:251-260.

21. Rademakers, J. L. W., Louws, F. J., and de Bruijn, F. J. 1998. Characterization of the diversity of ecologically important microbes by rep-PCR genomic fingerprinting. Section 3.4.3 in: Molecular Microbial Ecology Manual. A. D. L. Akkermans, J. D. van Elsas, and F. J. de Bruijn, eds. Kluwer Academic Publishers, Dordrecht, the Netherlands.

22. Reissbrodt, R., Rienaecker, I., Romanova, J. M., Freestone, P. P. E., Haigh, R. D., Lyte, M., Tschäpe, H., and Williams, P. H. 2002. Resuscitation of Salmonella enterica serovar Typhimurium and enterohemorrhagic Escherichia coli from the viable but nonculturable state by heat-stable enterobacterial autoinducer. Appl. Environ. Microbiol. 68: 4788-4794
23. Saile, E., McGarvey, J. A., Schell, M. A., and Denny, T. P. 1997. Role of extracellular polysaccharide and endoglucanase in root invasion and colonization of tomato plants by Ralstonia solanacearum. Phytopathology 87:1264-1271.

24. Thomas, C., Hill, D., and Mabey, M. 2002. Culturability, injury and morphological dynamics of thermophilic Campylobacter spp. within a laboratory-based aquatic model system. J. Appl. Microbiol. 92:433-442.

25. Van der Wolf, J. M., van Bekkum, P. J., van Elsas, J. D., Nijhuis, E. H. Vriend, S. G. C., and Ruissen, M. A. 1998. Immunofluorescence colony staining and selective enrichment in liquid medium for studying the population dynamics of Ralstonia solanacearum (race 3) in soil. OEPP (Organ. Eur. Mediterr. Prot.)/EPPO (Eur. Mediterr. Plant Prot. Organ.) Bull. 28:71-79.

26. Van Elsas, J. D., Kastelein, P., de Vries, P. M., and van Overbeek, L. S. 2001. Effects of ecological factors on the survival and physiology of Ralstonia solanacearum biovar 2 in agricultural drainage water. Can. J. Microbiol. 47:842-854.

27. Van Elsas, J. D., Kastelein, P., van Bekkum, P., van der Wolf, J. M., de Vries, P. M., and van Overbeek, L. S. 2000. Survival of Ralstonia solanacearum biovar 2 , the causative agent of potato brown rot, in field and microcosm soils in temperate climates. Phytopathology 90:13581366.

28. Van Ginkel, J. H., Merckx, R., and van Veen, J. A. 1994. Microbial biomass method based on soluble carbon in the soil solution. Soil Biol. Biochem. 26:417-419.

29. Van Overbeek, L. S., Cassidy, M., Kozdroj, J., Trevors, J. T., and van Elsas, J. D. 2002. A polyphasic approach for studying the interaction between Ralstonia solanacearum and potential control agents in the tomato phytosphere. J. Microbiol. Methods 48:69-86.

30. Van Overbeek, L. S., and van Elsas, J. D. 1995. Root exudate induced promoter activity in Pseudomonas fluorescens mutants in the wheat rhizosphere. Appl. Environ. Microbiol. 61:890-898.

31. Van Vuurde, J. W. L., and van der Wolf, J. M. 1995. Immunofluorescence colony-staining (IFC). Section 4.1.3 in: Molecular Microbial Ecology Manual. A. D. L. Akkermans, J. D. Van Elsas, and F. J. de Bruijn, eds. Kluwer Academic Publishers, Dordrecht, the Netherlands.

32. Wai, S. N., Mizunoe, Y., Takade, A., and Yoshida, S. 2000. A comparison of solid and liquid media for resuscitation of starvation- and lowtemperature-induced nonculturable cells of Aeromonas hydrophila. Arch. Microbiol. 173:307-310.

33. Wakimoto, U. I., Matsuo, N., and Hayashi, I. 1982. Multiplication of Pseudomonas solanacearum in pure water. Annu. Rev. Phytopathol. Soc. Jpn. 48:620-627.

34. Weichart, D. H. 2000. Stability and survival of VBNC cells-conceptual and practical implications. Pages 731-736 in: New Frontiers. Proc. 8th Int. Symp. Microbial Ecol. C. R. Bell, M. Brylinski, and P. JohnsonGreen, eds. Atlantic Canada Society for Microbial Ecology, Halifax, Canada.

35. Wenneker, M., Verdel, M. S. W., Groeneveld, R. M. W., Kempenaar, C., van Beuningen, A. R., and Janse, J. D. 1999. Ralstonia (Pseudomonas) solanacearum race 3 (biovar 2 ) in surface water and natural weed hosts: First report on stinging nettle (Urtica dioica). Eur. J. Plant Pathol. 105:307-315.

36. Whitesides, M. D., and Oliver, J. D. 1997. Resuscitation of Vibrio vulnificus from the viable but nonculturable state. Appl. Environ. Microbiol. 63:1002-1005 